Article

\title{
Hydrophobic Ceramic Membranes for Water Desalination
}

\author{
Joanna Kujawa $^{1}$, Sophie Cerneaux ${ }^{2}$, Wojciech Kujawski ${ }^{1 \text {, }}$ and Katarzyna Knozowska ${ }^{1}$ \\ 1 Faculty of Chemistry, Nicolaus Copernicus University in Torun, 7 Gagarina St., 87-100 Torun, Poland; \\ joanna.kujawa@umk.pl (J.K.); kasiaknozowska@wp.pl (K.K.) \\ 2 Institut Europeen des Membranes, UMR 5635, Place Eugene Bataillon, 34095 Montpellier CEDEX 5, France; \\ Sophie.Cerneaux@univ-montp2.fr \\ * Correspondence: wojciech.kujawski@umk.pl; Tel.: +48-56-611-43-15; Fax: +48-56-611-45-26
}

Academic Editor: Enrico Drioli

Received: 26 January 2017; Accepted: 13 April 2017; Published: 15 April 2017

\begin{abstract}
Hydrophilic ceramic membranes (tubular and planar) made of $\mathrm{TiO}_{2}$ and $\mathrm{Al}_{2} \mathrm{O}_{3}$ were efficiently modified with non-fluorinated hydrophobic grafting molecules. As a result of condensation reaction between hydroxyl groups on the membrane and reactive groups of modifiers, the hydrophobic surfaces were obtained. Ceramic materials were chemically modified using three various non-fluorinated grafting agents. In the present work, the influence of grafting time and type of grafting molecule on the modification efficiency was evaluated. The changes of physicochemical properties of obtained hydrophobic surfaces were determined by measuring the contact angle (CA), roughness (RMS), and surface free energy (SFE). The modified surfaces were characterized by contact angle in the range of $111-132^{\circ}$. Moreover, hydrophobic tubular membranes were utilized in air-gap membrane distillation to desalination of sodium chloride aqueous solutions. The observed permeate fluxes were in the range of $0.7-4.8 \mathrm{~kg} \cdot \mathrm{m}^{-2} \cdot \mathrm{h}^{-1}$ for tests with pure water. The values of permeate fluxes for membranes in contact with $\mathrm{NaCl}$ solutions were smaller, within the range of $0.4-2.8 \mathrm{~kg} \cdot \mathrm{m}^{-2} \cdot \mathrm{h}^{-1}$. The retention of $\mathrm{NaCl}$ in AGMD process using hydrophobized ceramic membranes was close to unity for all investigated membranes.
\end{abstract}

Keywords: ceramic membranes; non-fluorinated alkylsilanes; air-gap membrane distillation

\section{Introduction}

Membrane distillation (MD) is an emerging non-isothermal membrane separation process, being one of the promising techniques for the desalination of highly saline waters [1-7]. Contrary to pressure-driven techniques, the driving force in the membrane distillation process is related to the difference in chemical potential (generated by difference of temperatures) between the two sides of the hydrophobic membrane [8-10]. The non-wetted porous hydrophobic membranes are required for an efficient process realization. There are various MD modes utilized, for example, sweep gas membrane distillation (SGMD), direct contact membrane distillation (DCMD), air gap membrane distillation (AGMD), vacuum membrane distillation (VMD) $[1,5,9,11]$. MD can be used in different applications such as waste water treatment, desalination, and food processing [1,3,5,11-19]. In all configurations, the liquid-vapor equilibrium is the determining factor yielding to the selectivity of the MD processes. The mass transfer in MD follows three subsequent steps: liquid-vapor phase transition at the membrane pores entrance on feed side; transfer of vapors through the pores of the membrane; and condensation of vapors on the permeate side of the membrane [1-7].

Despite the fact that, in the MD process, high pressure is not required and the process offers a very promising performance for both the stand-alone and the desalination process, full-scale commercialization of MD still copes with various problems. These difficulties are related to the lack of 
suitable and effective module design, proper membranes, as well as intensive energy consumption (in cases when waste heat, solar, or different alternative energy sources are not utilized). In the presented article, the authors address the issues related to the lack of suitable membranes. The major requirements for the membrane features are related to hydrophobic character and porous structure [20]. During the MD process only vapors of solvent (water) are allowed to pass across the membrane. Concerning scientific literature focused on MD application, it is possible to find application of commercially-available hollow fiber or flat-sheet microfiltration membranes [16,21-29]. The utilization of these membranes in MD is associated with their hydrophobic properties, decent porosity, as well as adequate pore sizes. Nevertheless, these membranes are not the perfectly-designed and dedicated to membrane distillation, therefore they suffer from wetting problems as well as low permeability and short life span $[9,21-26,30]$.

To design and form hydrophobic surfaces with certain properties, two approaches can be selected. One possibility is the creation of a rough surface with a structure responsible for its hydrophobicity. By generating heterogeneity on the surface, it is possible to form highly hydrophobic surfaces due to generation of pillars and the presence of air pockets on the surface. The other way is utilization of chemical modification applying grafting agent materials possessing the low surface free energy [31,32]. Up till now, a number of methods have been developed to produce rough surfaces, like solidification of melted alkylketene dimer (AKD) [33], plasma polymerization/etching of polypropylene in the presence of polytetrafluoroethylene (PTFE) [34], microwave plasma-enhanced chemical vapor deposition (MWPE-CVD) of trimethylmethoxysilane (TMMOS) [35], anodic oxidization of aluminum [36], or an immersion of porous alumina gel films into boiling water [37]. Chemically attached coupling agents with low-surface-energy can be also efficiently used to turn the hydrophilic character materials to hydrophobic one [38-41]. Within that group of compounds, perfluoroalkylsilane (PFAS) molecules [42-45], hydrophobic polymers [46], as well as Grignard compounds [47,48] have been found to generate hydrophobic surfaces. The aforementioned grafting agents were efficiently modified by the chemical attachment to the ceramic support. Ceramic materials are characterized by high chemical, thermal, and mechanical stability; therefore, they are ideal materials for many applications in the chemical, biotechnological [49,50], food [51], and pharmaceutical industries [52,53], as well as in water and wastewater processing [40,41,49]. However, ceramic membranes are hydrophilic by nature. This material property limits the wider application of ceramic membranes. For that particular reason, the modification of membrane surface is required to change the surface character from hydrophilic to hydrophobic one. Considering the high effectiveness of the grafting process of ceramic materials and good performance in membrane-based separation techniques (e.g., vacuum pervaporation [42,43,54,55], vacuum membrane distillation [56], air-gap and direct membrane distillation $[42,45]$, and organic solvent nanofiltration $[47,48,57])$ it should be pointed out that such modification also possessed disadvantages. Namely, a significant drawback is the presence of fluorine atoms in coupling agents. In the presented research fluorine-free modifiers were used for highly efficient hydrophobization process of ceramic membranes. Subsequently, the ceramic materials are tested in desalination process using membrane distillation (MD) technique. An important issue of the study was to evaluate the influence of the type of grafting agents and modification conditions on the membrane performance in MD.

\section{Materials and Methods}

\subsection{Materials}

$\mathrm{Al}_{2} \mathrm{O}_{3}$ (Pall Exekia, Bazet, France) and $\mathrm{TiO}_{2}$ (TAMI Industries, Nyons, France) tubular ceramic membranes were used in the presented work. Alumina membranes possessed $100 \mathrm{~nm}$ pore size $(\mathrm{MWCO} \approx 150 \mathrm{kDa})$, whereas titania ones were characterized by $100 \mathrm{kD}(\approx 75 \mathrm{~nm})$ molecular weight cut-off (MWCO). Both types of membranes were characterized by $10 / 5 \mathrm{~mm}$ of outer/inner diameters 
and $150 \mathrm{~mm}$ length. Additionally, $\mathrm{TiO}_{2} 100 \mathrm{kD}$ planar membranes (TAMI Industries, France) were used for material characterization.

The following grafting compounds were purchased from Linegal Chemicals (Poland): n-octyltrichlorosilane (C8Cl3); n-octyltriethoxysilane (C8OEt3); and trichloro(octadecyl)silane (C18Cl3) were used. Chloroform (stabilized by $1 \%$ ethanol), acetone, ethanol, $n$-butanol, $n$-hexane, and glycerin were purchased from Avantor Performance Materials (Poland). All compounds and chemicals were used as received.

\subsection{Experimental Protocol of Ceramic Membranes Modification}

Grafting solutions $(0.05 \mathrm{M})$ were prepared by dissolving an appropriate amount of alkylsilanes in chloroform (stabilized by $1 \%$ ethanol). The preparation steps and modification were performed under inert gas (argon) atmosphere to avoid polycondensation reaction [31-41]. Prior to grafting, the ceramic membranes (tubular and/or planar) were cleaned consecutively in ethanol, acetone, and distilled water for $10 \mathrm{~min}$ in each solvent and dried in an oven at $110^{\circ} \mathrm{C}$ for $12 \mathrm{~h}$. Subsequently, ceramic supports were modified by soaking samples in the grafting solution for a given period of time equal to $1.5 \mathrm{~h}$ followed by the second modification of $3 \mathrm{~h}$ what resulted in the total hydrophobization time equal to $4.5 \mathrm{~h}$. Scheme of modification procedure is depicted in Figure 1. Subsequently, the grafting effectiveness was evaluated by the contact angle measurements in the case of planar membranes and by determination of water liquid entry pressure (LEPw) for tubular ceramics.

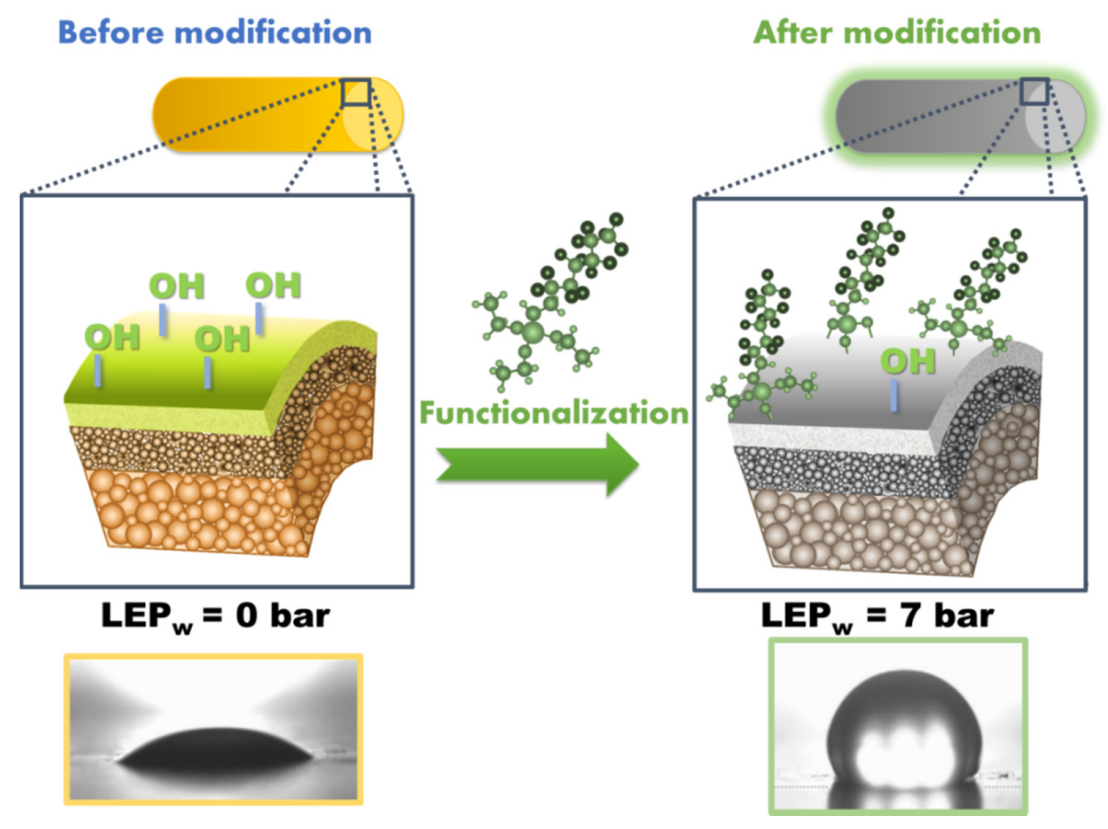

Figure 1. Ceramic membrane modification by alkylsilanes grafting agent and differences in hydrophobicity level (contact angle and water liquid entry pressure (LEPw)) before (left) and after (right) hydrophobization process.

\subsection{Modified Membrane Characterization-Analytical Methods}

Contact Angle (CA) and Surface Free Energy (SFE): Static and dynamic contact angles (CA) measurements were performed at room temperature using the goniometer PG-X (FibroSystem $\mathrm{AB}$ ) and deionized water $(18 \mathrm{M} \Omega \mathrm{cm})$ and glycerin as testing liquids. CAs were determined for pristine and grafted membranes, based on sessile drop (static CA) and the tilting plate (dynamic CA) methods described elsewhere [44,45]. The apparent CA values were calculated by ImageJ software (ImageJ, $\mathrm{NIH}$-freeware version), with an accuracy of $\pm 2^{\circ}$. Additionally, a contact goniometric analysis was implemented for surface free energy (SFE) assessment for planar ceramic membranes. SFE was 
calculated based on the Owens-Wendt method [58]. The results are presented as an average value obtained from 20 to 30 measurements (average accuracy of $\pm 5 \%$ ).

Atomic force microscopy (AFM): This technique was used for surface analysis (topography and phase analysis) of planar membranes (NanoScope MultiMode SPM System and NanoScope IIIa Quadrex controller-Veeco, Digital Instrument, Saint Ives, Cambridgeshire, UK). Tip scanning mode was applied for surface roughness analysis. Ambient temperature conditions were kept during all experiments. The root mean squared (RMS) roughness was used as a parameter describing heterogeneity of the samples. Scan size areas were equal to $5 \times 5 \mu \mathrm{m}$. All samples were analyzed at least five times and an average value of RMS was calculated (accuracy $\pm 5 \%$ ).

Liquid entry pressure (LEPw): The grafting effectiveness of tubular membranes was assessed by liquid entry pressure determination (LEPw) -Equation (1). LEPw is a pressure value at which liquid penetrates across open pores of the membrane and is transported through the hydrophobic layer on the permeate side $[11,23,42,59]$. According to the Laplace-Young equation (Equation (1)), it can be noticed that LEPw value refer to the surface tension $\left(\gamma_{\mathrm{L}}\right)$, contact angle $\left(\theta_{\mathrm{ef}}\right)$ on membrane surface, pore radius (r), and tortuosity factor (B).

$$
\mathrm{LEP}_{\mathrm{w}}=-\mathrm{B} \frac{2 \gamma_{\mathrm{L}}}{\mathrm{r}} \cos \theta_{\mathrm{ef}}
$$

The LEPw measurements were realized using a laboratory experimental rig presented in detail elsewhere [42]. LEPw values were determined for all tubular membrane samples, prior to the membrane characterization in membrane distillation process. During the LEP measurements, the time interval between each pressure step was equal to $60 \mathrm{~min}$.

\subsection{Air-Gap Membrane Distillation (AGMD)}

Membranes efficiency was evaluated in desalination process using air-gap membrane distillation (AGMD) technique and experimental rig presented in Figure 2. The AGMD experimental setup and the detailed experimental protocol are described elsewhere [42,45]. AGMD process was realized at temperate of feed equal to $\mathrm{T}_{\mathrm{f}}=90^{\circ} \mathrm{C}$ and permeate equal to $\mathrm{T}_{\mathrm{p}}=5{ }^{\circ} \mathrm{C}$. The air gap width was equal to $5 \mathrm{~mm}$ (Figure 2). Measurements were realized for pure water and for the following feed concentrations of $\mathrm{NaCl}$ aqueous solutions: $0.25,0.5,0.75$, and $1.0 \mathrm{M}$. Rejection coefficient of sodium chloride (Equation (2)) was controlled by ion chromatography (Dionex DX-100 Ion Chromatograph).

$$
\mathrm{R}_{\mathrm{NaCl}}=\left(1-\frac{\mathrm{C}_{p}}{\mathrm{C}_{f}}\right) \times 100(\%)
$$

where $\mathrm{C}_{p}$ and $\mathrm{C}_{f}$ stand for the $\mathrm{NaCl}$ concentration in permeate and feed solution, respectively.

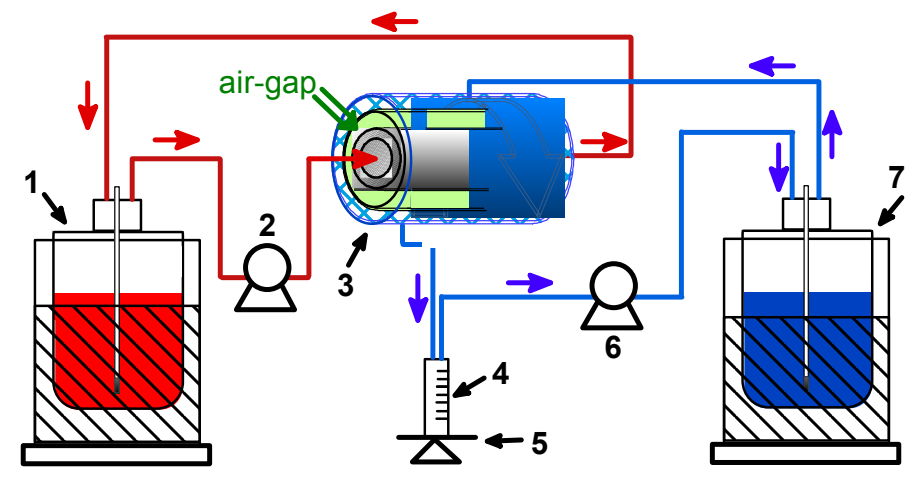

Figure 2. Scheme of a setup used in AGMD experiments (1-thermostated feed tank; 2 and 6-pump; 3-AGMD thermostated membrane module with air gap = $5 \mathrm{~mm}$; 4-measuring cylinder; 5-balance; 7-cooling system). 


\section{Results and Discussion}

\subsection{Pristine Ceramic Membranes}

Planar unmodified $\mathrm{TiO}_{2} 100 \mathrm{kD}$ membrane possessed hydrophilic character with a surface contact angle value equal to $40 \pm 2^{\circ}$ and total surface free energy equal to $140 \pm 5 \mathrm{mN} \cdot \mathrm{m}^{-1}$ (polar part $44.8 \pm 1.4 \mathrm{mN} \cdot \mathrm{m}^{-1}$; dispersive part $\left.95.2 \pm 3.1 \mathrm{mN} \cdot \mathrm{m}^{-1}\right)$. Roughness of unmodified ceramic sample expressed by RMS was equal to $60.5 \pm 5.1 \mathrm{~nm}$. Pristine tubular membranes $\mathrm{TiO}_{2} 75 \mathrm{~nm}$ and $\mathrm{Al}_{2} \mathrm{O}_{3}$ $100 \mathrm{~nm}$ were characterized by LEPw equal to 0 bar.

\subsection{Effectiveness of Membrane Hydrophobization}

The hydrophilic character of planar membrane was turned to hydrophobic one with high efficiency. As a result of hydrophobization, the changes in morphology and physicochemistry of the membrane surface are clearly noticeable (Table 1). All membrane samples possessed contact angle values higher than $90^{\circ}$. The significant increase of water contact angle confirms the formation of the hydrophobic surface. Based on results presented in Table 1, it can be concluded that modification conditions (time and type of grafting agent) have an essential impact on the resulting hydrophobicity level. The highest value of CA was found for samples modified by $\mathrm{C} 18 \mathrm{Cl} 3$ molecules, i.e., the molecules with the longest hydrocarbon chain $(\sim 2.3 \mathrm{~nm})$. Moreover, comparing ceramics grafted by silanes possessing the same length of alkyl chains, higher $\mathrm{CA}$ value was found for $\mathrm{C} 8 \mathrm{Cl} 3$ than for $\mathrm{C} 8 \mathrm{OEt} 3$. This observation is related to the bond dissociation energy which is equal to $489.5 \mathrm{~kJ} \mathrm{~mol}^{-1}$ and $510.5 \mathrm{~kJ} \mathrm{~mol}^{-1}$ for $\mathrm{Si}-\mathrm{Cl}$ and $\mathrm{Si}-\mathrm{OEt}$, respectively [60]. Similar relation was found for ceramic powders $\left(\mathrm{TiO}_{2}\right.$ and $\left.\mathrm{ZrO}_{2}\right)$ modified by non-fluorinated compounds possessing various reactive groups (e.g., methoxy, ethoxy, and chlorine atoms) [44]. The grafting process affects physicochemistry of ceramics, which was proved by the resulting reduction of surface free energy (SFE) value. It was found that polar component $\left(\gamma^{\mathrm{p}}\right)$ in overall SFE is very small (Table 1$)$. Small contribution of the polar part compared to the dispersive component $\left(\gamma^{\mathrm{d}}\right)$ of SFE is characteristic for hydrophobic and highly hydrophobic materials [42,45,58,61]. Hydrophobization process also influences the surface roughness. The roughness parameter is reduced after grafting and it decreased even more after the extension of grafting duration. Silanization generated smoother surfaces with higher level of hydrophobicity. Namely, the smoothest surface possessing simultaneously the lowest value of overall SFE was achieved for samples modified by $\mathrm{C} 18 \mathrm{Cl} 3$ during $4.5 \mathrm{~h}$.

Table 1. Characterization of modified planar ceramic membrane.

\begin{tabular}{cccccccc}
\hline \multirow{2}{*}{ Parameter } & Pristine & \multicolumn{2}{c}{ Ti-C8OEt3 } & \multicolumn{2}{c}{ Ti-C8Cl3 } & \multicolumn{2}{c}{ Ti-C18Cl3 } \\
\cline { 3 - 7 } & $\mathbf{1 . 5} \mathbf{h}$ & $\mathbf{4 . 5} \mathbf{h}$ & $\mathbf{1 . 5 h}$ & $\mathbf{4 . 5} \mathbf{h}$ & $\mathbf{1 . 5} \mathbf{h}$ & $\mathbf{4 . 5} \mathbf{~ h}$ \\
\hline $\begin{array}{c}\text { Contact angle (CA), } \\
\text { deg }\end{array}$ & $40 \pm 2$ & $111 \pm 2$ & $113 \pm 2$ & $120 \pm 2$ & $128 \pm 2$ & $126 \pm 2$ & $132 \pm 2$ \\
\hline SFE, $\mathrm{mN} \cdot \mathrm{m}^{-1}$ & $140 \pm 5$ & $62.5 \pm 2.7$ & $53.6 \pm 2.3$ & $43.7 \pm 1.9$ & $32.7 \pm 1.4$ & $38.2 \pm 1.7$ & $31.1 \pm 1.4$ \\
\hline $\begin{array}{c}\text { Polar part of SFE } \\
\left(\gamma^{\mathrm{p}}\right), \mathrm{mN} \cdot \mathrm{m}^{-1}\end{array}$ & $44.8 \pm 1.4$ & $13.3 \pm 0.6$ & $11.4 \pm 0.5$ & $9.3 \pm 0.4$ & $8.6 \pm 0.4$ & $5.7 \pm 0.3$ & $5.5 \pm 0.2$ \\
\hline $\begin{array}{c}\text { Dispersive part of } \\
\mathrm{SFE}\left(\gamma^{\mathrm{d}}\right), \mathrm{mN} \cdot \mathrm{m}^{-1}\end{array}$ & $95.2 \pm 3.1$ & $49.2 \pm 2.2$ & $42.2 \pm 1.8$ & $34.4 \pm 1.5$ & $24.1 \pm 1.1$ & $32.5 \pm 1.4$ & $25.6 \pm 1.1$ \\
\hline $\mathrm{RMS}, \mathrm{nm}$ & $60.5 \pm 5.1$ & $50.9 \pm 2.0$ & $45.2 \pm 1.8$ & $39.6 \pm 1.6$ & $33.2 \pm 1.3$ & $27.8 \pm 1.1$ & $22.9 \pm 0.9$ \\
\hline
\end{tabular}

The efficiency of tubular membranes modification was assessed by determining LEPw values for alumina and titania membranes after $1.5 \mathrm{~h}$ and $4.5 \mathrm{~h}$ of modification (Figure 3). A substantial influence of grafting time on the LEPw values, especially for samples grafted by $\mathrm{C} 18 \mathrm{Cl} 3$ molecules (Figure 3) was observed. After $1.5 \mathrm{~h}$ of hydrophobization LEPw value equal to 1 bar for alumina and titania membranes were observed. Longer exposure of membranes to the grafting agent resulted 
in the increase of LEPw values to 7 bar and 4 bar for $\mathrm{Al}_{2} \mathrm{O}_{3}$ and $\mathrm{TiO}_{2}$ membrane, respectively. The highlighted differences between ceramics can be linked to the membrane material and availability of different amounts of hydroxyl groups available to generate covalent bonds between ceramic surface and grafting coupling agent. Concerning the material properties of ceramics and data presented elsewhere [44], it was found that alumina is richer in hydroxyl groups comparing with titania. For this reason, higher value of $\mathrm{LEPw}$ for $\mathrm{Al}_{2} \mathrm{O}_{3}$ has been noticed. A slightly higher value of LEPw for C8OEt3 than $\mathrm{C} 8 \mathrm{Cl} 3$ after a longer modification time might be related to the presence of hydroxyl groups still available after the first grafting process that were not used for covalent bonding.

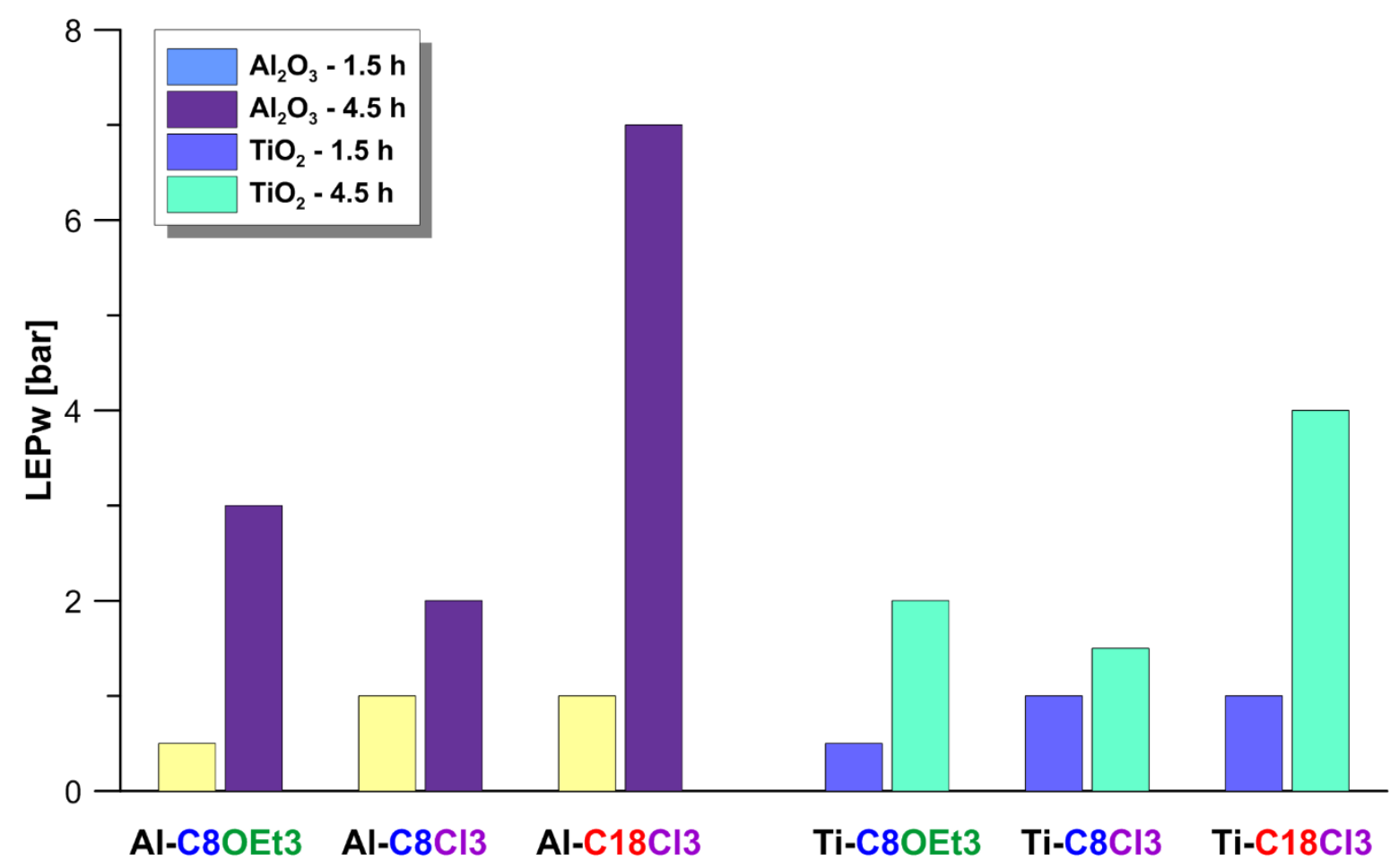

Figure 3. LEPw evolution with grafting time for alumina and titania ceramic materials grafted with various alkylsilanes.

\subsection{Air-Gap Membrane Distillation—Separation Efficiency of Modified Ceramic Membranes}

Prior to desalination process of $\mathrm{NaCl}$ solutions, membranes were tested in contact with pure water as a feed solution to evaluate the nominal value of water permeate flux (Figure 4). The fluxes in contact with pure water were the higher that those for $\mathrm{NaCl}$ solutions. Membrane grafted by C8COEt3 possessed the highest value of permeate flux (Figure 4). On the other hand, the less permeable was the membrane grafted by molecules having the longest alkyl chains. The permeate flux through the grafted ceramic membranes decreased with increasing salt concentration in the feed (Figure 4). This behavior was caused by the fact that, in membrane distillation of $\mathrm{NaCl}$ solutions, only vapors of water are transported across the hydrophobic porous structure of the membrane and with higher concentration of non-volatile compounds in the feed (sodium chloride) a decline of the flux is observed. For this reason, with increase of salt concertation a diminution of driving can be noticed, according to the Raoult's law. 

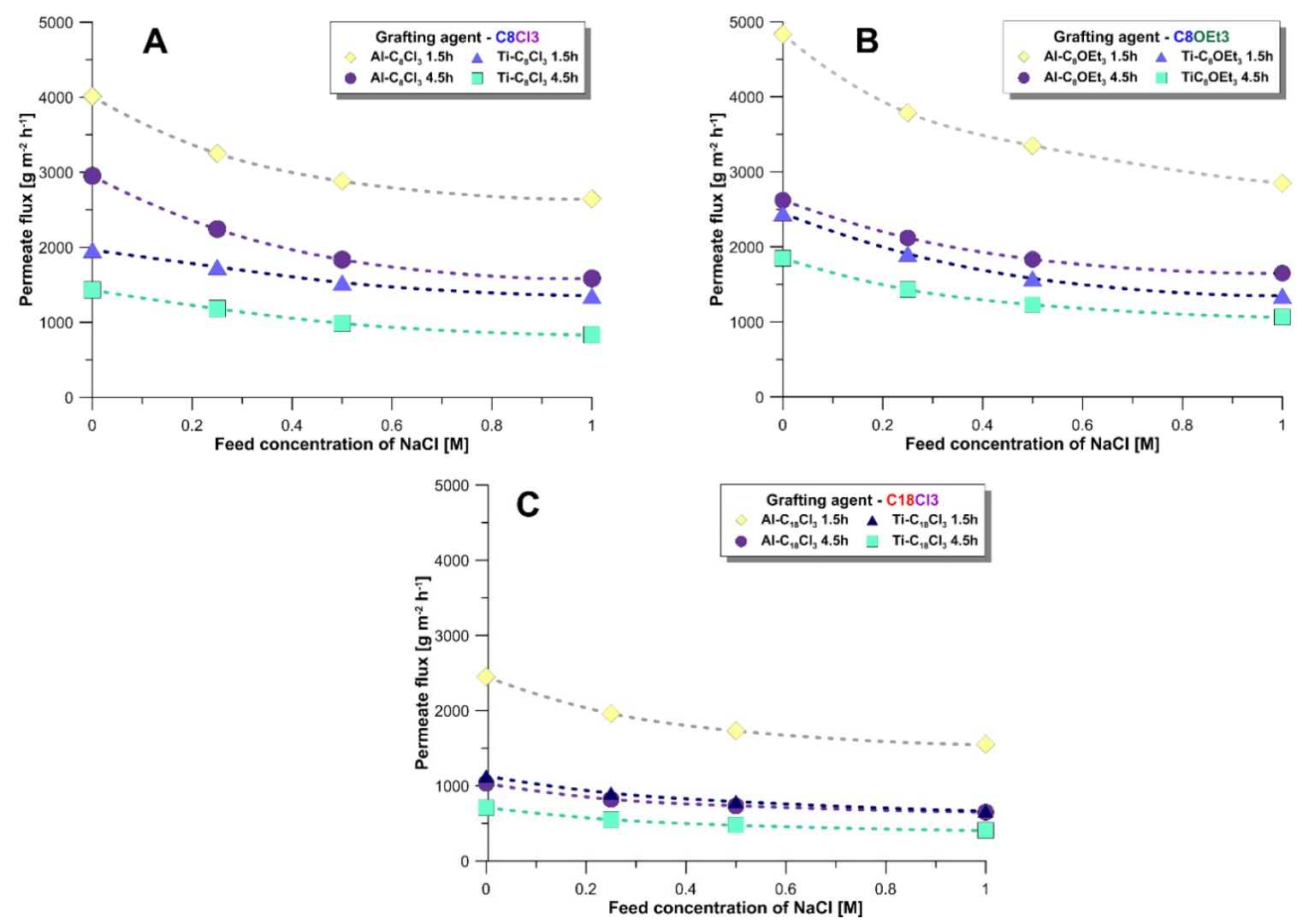

Figure 4. Transport properties of modified ceramic membranes by (A) C8Cl3; (B) C8OEt3; and (C) $\mathrm{C} 18 \mathrm{Cl} 3$, molecules in AGMD process used for desalination. $\mathrm{T}_{\mathrm{f}}=90^{\circ} \mathrm{C} ; \mathrm{T}_{\mathrm{p}}=5^{\circ} \mathrm{C}, \Delta \mathrm{p}=688 \mathrm{mbar}$.

After a shorter grafting $(1.5 \mathrm{~h})$, the alumina membrane modified by $\mathrm{C} 8 \mathrm{OEt} 3$ molecules showed the highest value of permeate flux $4.84 \mathrm{~kg} \mathrm{~m}^{-2} \cdot \mathrm{h}^{-1}$ which corresponded to the lowest value of measured LEPw (Figure 4B). On the other hand, a membrane sample hydrophobized by molecules with longer alkyl chain $(\mathrm{C} 18 \mathrm{Cl})$ showed the poorest transport properties. This can be attributed to the presence of alkyl chain in a tangled environment and/or partially located in pores [56].

The Al-C18Cl3 membranes produced the lowest value of permeate flux. This observation can be explain by a higher effectiveness of grafting comparing molecules with reactive groups of chlorine atoms and ethoxyl groups. As mentioned above, molecules with chlorine atoms are characterized by the highest ability to generate covalent bonds due to the lower value of energy bonds [60]. The membrane material as well as time of modification process affected the transport properties. Generally, membranes made from alumina possessed a slightly higher value of permeate flux due to slightly bigger pores $(100 \mathrm{~nm})$ in comparison with titania ones $(\approx 75 \mathrm{~nm})$. The observed reduction of permeate fluxes (Figure 4) as well as LEPw values (Figure 3) with extended grafting time contributed to formation of a smoother surface (Table 1) showing better water-proof character. Summarizing the fabricated hydrophobic membranes possess good transport properties in AGMD compared with literature data $[40,42,62,63]$. Furthermore, the observed values of permeate fluxes are higher than for ceramic membranes tested in DCMD. This is related to the benefit of AGMD, namely the reduction of conduction heat losses. In AGMD, permeate is condensed on a chilled surface rather than directly in the chilled permeate. Nevertheless, the achieved permeate fluxes for ceramic membranes are smaller than for polymeric one [64].

Retention coefficient of salt $\left(\mathrm{R}_{\mathrm{NaCl}}\right)$ Equation (2) is a very important factor determining efficiency of membrane distillation process. $\mathrm{R}_{\mathrm{NaCl}}$ corresponds to the separation properties of applied membranes. The salt retention $\left(\mathrm{R}_{\mathrm{NaCl}}\right)$ during the membrane distillation process was calculated according to Equation (2). The obtained values of $\mathrm{R}_{\mathrm{NaCl}}$ were very high, close to $100 \%$ (Table 2). A small effect 
of grafting time on the $\mathrm{R}_{\mathrm{NaCl}}$ values was observed. On the other hand, no influence of membrane materials on their selective properties was noticed. The observed small alteration in $\mathrm{R}_{\mathrm{NaCl}}$ values can be explained by marginal differences in physiochemistry of the membrane (CA, LEPw, and RMS). Nevertheless, the value of $\mathrm{R}_{\mathrm{NaCl}}$ was high, proving that no wetting of the membranes was observed.

Table 2. Range of retention coefficient (\%) of $\mathrm{NaCl}$ in AGMD process.

\begin{tabular}{ccc}
\hline Membrane & 1.5 $\mathbf{~ h ~ M o d i f i c a t i o n}$ & 4.5 h Modification \\
\hline Ti-C8Cl3 & $98.0-98.3$ & $99.5-99.6$ \\
Ti-C8OEt3 & $98.3-98.5$ & $99.6-99.7$ \\
Ti-C18Cl3 & $98.0-98.4$ & $99.2-99.6$ \\
Al-C8Cl3 & $98.1-98.3$ & $99.0-99.5$ \\
Al-C8OEt3 & $98.0-98.3$ & $99.0-99.3$ \\
Al-C18Cl3 & $98.0-98.2$ & $99.0-99.3$ \\
\hline
\end{tabular}

\section{Conclusions}

The surface character of $\mathrm{Al}_{2} \mathrm{O}_{3}$ and $\mathrm{TiO}_{2}$ ceramic membranes (tubular and planar) was changed from a hydrophilic to hydrophobic one by chemical modification with silane grafting agents possessing various structures (length of alkyl chain and type of reactive groups). After modification, highly hydrophobic surfaces were fabricated.

The length of hydrophobic PFAS molecule has a significant impact on the hydrophobicity level. Much higher values of CA and LEPw were observed for planar and tubular membranes grafted by C18 molecules comparing with C8 ones.

Hydrophobization process changed the physicochemical properties of ceramic membranes expressed by their roughness, surface free energy (polar and dispersive component), and hydrophobicity level.

The obtained hydrophobic tubular ceramic membranes were used in membrane separation process-air gap membrane distillation. In AGMD, process impact of concentration of $\mathrm{NaCl}$ in the feed, grafting time, as well as type of membrane materials on the transport properties was observed and discussed in detail. Higher values of permeate flux were observed for alumina membranes than for titiania ones, which resulted from higher LEPw values for grafted alumina. The retention coefficient of $\mathrm{NaCl}$ in AGMD process using hydrophobized ceramic membranes was over $98 \%$ for all investigated membranes.

Acknowledgments: This research was supported by NN 209255138 grant from the Polish Ministry of Science and Higher Education and by 2012/07/N/ST4/00378 (Preludium 4) grant from the National Science Centre. This research was also partially supported by statutory funds of Nicolaus Copernicus University in Torun (Faculty of Chemistry, T-109 "Membranes and membrane separation processes—fundamental and applied research").

Author Contributions: Joanna Kujawa and Wojciech Kujawski conceived and designed the experiments; Joanna Kujawa and Sophie Cerneaux performed experiments and collaborated with the data analysis; Katarzyna Knozowska collaborated with interpretation of the experimental data (contact angle, membrane distillation), assisted with critical corrections in the manuscript drafting, and prepared the drawings; Joanna Kujawa and Wojciech Kujawski participated in the analysis and interpretation of the experimental data, cooperated with the drafting and correction of the final version of the manuscript.

Conflicts of Interest: The authors declare no conflict of interest.

\section{References}

1. Woo, Y.C.; Tijing, L.D.; Shim, W.-G.; Choi, J.-S.; Kim, S.-H.; He, T.; Drioli, E.; Shon, H.K. Water desalination using graphene-enhanced electrospun nanofiber membrane via air gap membrane distillation. J. Membr. Sci. 2016, 520, 99-110. [CrossRef]

2. Quist-Jensen, C.A.; Macedonio, F.; Conidi, C.; Cassano, A.; Aljlil, S.; Alharbi, O.A.; Drioli, E. Direct contact membrane distillation for the concentration of clarified orange juice. J. Food Eng. 2016, 187, 37-43. [CrossRef] 
3. Wang, P.; Chung, T.-S. Recent advances in membrane distillation processes: Membrane development, configuration design and application exploring. J. Membr. Sci. 2015, 474, 39-56. [CrossRef]

4. Drioli, E.; Ali, A.; Simone, S.; Macedonio, F.; Al-Jlil, S.A.; Al Shabonah, F.S.; Al-Romaih, H.S.; Al-Harbi, O.; Figoli, A.; Criscuoli, A. Novel pvdf hollow fiber membranes for vacuum and direct contact membrane distillation applications. Sep. Purif. Technol. 2013, 115, 27-38. [CrossRef]

5. Quist-Jensen, C.A.; Macedonio, F.; Horbez, D.; Drioli, E. Reclamation of sodium sulfate from industrial wastewater by using membrane distillation and membrane crystallization. Desalination 2017, 401, 112-119. [CrossRef]

6. El-Bourawi, M.S.; Ding, Z.; Ma, R.; Khayet, M. A framework for better understanding membrane distillation separation process. J. Membr. Sci. 2006, 285, 4-29. [CrossRef]

7. Alkhudhiri, A.; Darwish, N.; Hilal, N. Membrane distillation: A comprehensive review. Desalination 2012, 287, 2-18. [CrossRef]

8. Shannon, M.A.; Bohn, P.W.; Elimelech, M.; Georgiadis, J.G.; Marinas, B.J.; Mayes, A.M. Science and technology for water purification in the coming decades. Nature 2008, 452, 301-310. [CrossRef] [PubMed]

9. Drioli, E.; Wu, Y. Membrane distillation: An experimental study. Desalination 1985, 53, 339-346. [CrossRef]

10. Drioli, E.; Wu, Y.; Calabro, V. Membrane distillataion in the treatment of aqueous solutions. J. Membr. Sci. 1987, 33, 277-284. [CrossRef]

11. Zhang, H.; Liu, M.; Sun, D.; Li, B.; Li, P. Evaluation of commercial PTFE membranes for desalination of brine water through vacuum membrane distillation. Chem. Eng. J. 2016, 110, 52-63. [CrossRef]

12. Tong, D.; Wang, X.; Ali, M.; Lan, C.Q.; Wang, Y.; Drioli, E.; Wang, Z.; Cui, Z. Preparation of Hyflon AD60/PVDF composite hollow fiber membranes for vacuum membrane distillation. Sep. Purif. Technol. 2016, 157, 1-8. [CrossRef]

13. Rácz, G.; Kerker, S.; Schmitz, O.; Schnabel, B.; Kovács, Z.; Vatai, G.; Ebrahimi, M.; Czermak, P. Experimental determination of liquid entry pressure (LEP) in vacuum membrane distillation for oily wastewaters. Membr. Water Treat. 2015, 6, 237-249. [CrossRef]

14. Kujawa, J.; Guillen-Burrieza, E.; Arafat, H.A.; Kurzawa, M.; Wolan, A.; Kujawski, W. Raw juice concentration by osmotic membrane distillation process with hydrophobic polymeric membranes. Food Bioprocess Technol. 2015, 8, 2146-2158. [CrossRef]

15. Guo, F.; Servi, A.; Liu, A.; Gleason, K.K.; Rutledge, G.C. Desalination by membrane distillation using electrospun polyamide fiber membranes with surface fluorination by chemical vapor deposition. ACS Appl. Mater. Interfaces 2015, 7, 8225-8232. [CrossRef] [PubMed]

16. Criscuoli, A.; Carnevale, M.C. Desalination by vacuum membrane distillation: The role of cleaning on the permeate conductivity. Desalination 2015, 365, 213-219. [CrossRef]

17. Gryta, M. The application of membrane distillation for broth separation in membrane bioreactors. J. Membr. Sci. Res. 2016, 2, 193-200.

18. Dong, G.; Kim, J.F.; Kim, J.H.; Drioli, E.; Lee, Y.M. Open-source predictive simulators for scale-up of direct contact membrane distillation modules for seawater desalination. Desalination 2017, 402, 72-87. [CrossRef]

19. Gryta, M.; Tomaszewska, M.; Karakulski, K. Wastewater treatment by membrane distillation. Desalination 2006, 198, 67-73. [CrossRef]

20. Eykens, L.; De Sitter, K.; Dotremont, C.; Pinoy, L.; Van der Bruggen, B. How to optimize the membrane properties for membrane distillation: A review. Ind. Eng. Chem. Res. 2016, 55, 9333-9343. [CrossRef]

21. Peydayesh, M.; Kazemi, P.; Bandegi, A.; Mohammadi, T.; Bakhtiari, O. Treatment of bentazon herbicide solutions by vacuum membrane distillation. J. Water Process Eng. 2015, 8, e17-e22. [CrossRef]

22. Li, X.; Yu, X.; Cheng, C.; Deng, L.; Wang, M.; Wang, X. Electrospun superhydrophobic organic/inorganic composite nanofibrous membranes for membrane distillation. ACS Appl. Mater. Interfaces 2015, 7, 21919-21930. [CrossRef] [PubMed]

23. Guillen-Burrieza, E.; Servi, A.; Lalia, B.S.; Arafat, H.A. Membrane structure and surface morphology impact on the wetting of md membranes. J. Membr. Sci. 2015, 483, 94-103. [CrossRef]

24. Xu, W.-T.; Zhao, Z.-P.; Liu, M.; Chen, K.-C. Morphological and hydrophobic modifications of PVDF flat membrane with silane coupling agent grafting via plasma flow for VMD of ethanol-water mixture. J. Membr. Sci. 2015, 491, 110-120. [CrossRef]

25. Chen, K.; Xiao, C.; Huang, Q.; Liu, H.; Liu, H.; Wu, Y.; Liu, Z. Study on vacuum membrane distillation (VMD) using fep hollow fiber membrane. Desalination 2015, 375, 24-32. [CrossRef] 
26. Zaragoza, G.; Ruiz-Aguirre, A.; Guillén-Burrieza, E. Efficiency in the use of solar thermal energy of small membrane desalination systems for decentralized water production. Appl. Energy 2014, 130, 491-499. [CrossRef]

27. Drioli, E.; Ali, A.; Macedonio, F. Membrane distillation: Recent developments and perspectives. Desalination 2015, 356, 56-84. [CrossRef]

28. Michalkiewicz, B.; Ziebro, J.; Tomaszewska, M. Preliminary investigation of low pressure membrane distillation of methyl bisulphate from its solutions in fuming sulphuric acid combined with hydrolysis to methanol. J. Membr. Sci. 2006, 286, 223-227. [CrossRef]

29. Orecki, A.; Tomaszewska, M.U.; Morawski, A.W. Treatment of natural waters by nanofiltration. Przem. Chem. 2006, 85, 1067-1070.

30. Drioli, E. Guest editorial for the special issue: Membrane distillation and related membrane systems. Desalination 2013, 323, 1. [CrossRef]

31. Ahmad, N.A.; Leo, C.P.; Ahmad, A.L. Superhydrophobic alumina membrane by steam impingement: Minimum resistance in microfiltration. Sep. Purif. Technol. 2013, 107, 187-194. [CrossRef]

32. Bico, J.; Thiele, U.; Quéré, D. Wetting of textured surfaces. Colloids Surf. A Physicochem. Eng. Asp. 2002, 206, 41-46. [CrossRef]

33. Onda, T.; Shibuichi, S.; Satoh, N.; Tsujii, K. Super-water-repellent fractal surfaces. Langmuir 1996, 12, 2125-2127. [CrossRef]

34. Chen, W.; Fadeev, A.Y.; Hsieh, M.C.; Öner, D.; Youngblood, J.; McCarthy, T.J. Ultrahydrophobic and ultralyophobic surfaces: Some comments and examples. Langmuir 1999, 15, 3395-3399. [CrossRef]

35. Wu, Y.; Sugimura, H.; Inoue, Y.; Takai, O. Thin films with nanotextures for transparent and ultra water-repellent coatings produced from trimethylmethoxysilane by microwave plasma cvd. Chem. Vap. Depos. 2002, 8, 47-50. [CrossRef]

36. Tsujii, K.; Yamamoto, T.; Onda, T.; Shibuichi, S. Super oil-repellent surfaces. Angew. Chem. Int. Ed. 1997, 36, 1011-1012. [CrossRef]

37. Tadanaga, K.; Katata, N.; Minami, T. Formation process of super-water-repellent $\mathrm{Al}_{2} \mathrm{O}_{3}$ coating films with high transparency by the sol-gel method. J. Am. Ceram. Soc. 1997, 80, 3213-3216. [CrossRef]

38. Alami Younssi, S.; Iraqi, A.; Rafiq, M.; Persin, M.; Larbot, A.; Sarrazin, J. $\gamma$ alumina membranes grafting by organosilanes and its application to the separation of solvent mixtures by pervaporation. Sep. Sci. Technol. 2003, 32, 175-179. [CrossRef]

39. Kujawa, J.; Cerneaux, S.; Kujawski, W. Investigation of the stability of metal oxide powders and ceramic membranes grafted by perfluoroalkylsilanes. Colloids Surf. A Physicochem. Eng. Asp. 2014, 443, 109-117. [CrossRef]

40. Kujawa, J.; Kujawski, W.; Koter, S.; Jarzynka, K.; Rozicka, A.; Bajda, K.; Cerneaux, S.; Persin, M.; Larbot, A. Membrane distillation properties of $\mathrm{TiO}_{2}$ ceramic membranes modified by perfluoroalkylsilanes. Desalin. Water Treat. 2013, 51, 1352-1361. [CrossRef]

41. Kujawa, J.; Kujawski, W.; Koter, S.; Rozicka, A.; Cerneaux, S.; Persin, M.; Larbot, A. Efficiency of grafting of $\mathrm{Al}_{2} \mathrm{O}_{3}, \mathrm{TiO}_{2}$ and $\mathrm{ZrO}_{2}$ powders by perfluoroalkylsilanes. Colloid Surfaces A 2013, 420, 64-73. [CrossRef]

42. Kujawski, W.; Kujawa, J.; Wierzbowska, E.; Cerneaux, S.; Bryjak, M.; Kujawski, J. Influence of hydrophobization conditions and ceramic membranes pore size on their properties in vacuum membrane distillation of water-organic solvent mixtures. J. Membr. Sci. 2016, 499, 442-451. [CrossRef]

43. Kujawska, A.; Kujawski, J.K.; Bryjak, M.; Cichosz, M.; Kujawski, W. Removal of volatile organic compounds from aqueous solutions applying thermally driven membrane processes. 2. Air gap membrane distillation. J. Membr. Sci. 2016, 499, 245-256. [CrossRef]

44. Kujawa, J.; Kujawski, W. Functionalization of ceramic metal oxide powders and ceramic membranes by perfluoroalkylsilanes and alkylsilanes possessing different reactive groups: Physicochemical and tribological properties. ACS Appl. Mater. Interfaces 2016, 8, 7509-7521. [CrossRef] [PubMed]

45. Kujawa, J.; Cerneaux, S.; Kujawski, W.; Bryjak, M.; Kujawski, J. How to functionalize ceramics by perfluoroalkylsilanes for membrane separation process? Properties and application of hydrophobized ceramic membranes. ACS Appl. Mater. Interfaces 2016, 8, 7564-7577. [CrossRef] [PubMed]

46. Efome, J.E.; Baghbanzadeh, M.; Rana, D.; Matsuura, T.; Lan, C.Q. Effects of superhydrophobic $\mathrm{SiO}_{2}$ nanoparticles on the performance of PVDF flat sheet membranes for vacuum membrane distillation. Desalination 2015, 373, 47-57. [CrossRef] 
47. Hosseinabadi, S.R.; Wyns, K.; Buekenhoudt, A.; Van der Bruggen, B.; Ormerod, D. Performance of grignard functionalized ceramic nanofiltration membranes. Sep. Purif. Technol. 2015, 147, 320-328. [CrossRef]

48. Rezaei Hosseinabadi, S.; Wyns, K.; Meynen, V.; Carleer, R.; Adriaensens, P.; Buekenhoudt, A.; Van der Bruggen, B. Organic solvent nanofiltration with grignard functionalised ceramic nanofiltration membranes. J. Membr. Sci. 2014, 454, 496-504. [CrossRef]

49. Fane, A.G.; Schofield, R.W.; Fell, C.J.D. The efficient use of energy in membrane distillation. Desalination 1987, 64, 231-243. [CrossRef]

50. Qtaishat, M.R.; Banat, F. Desalination by solar powered membrane distillation systems. Desalination 2013, 308, 186-197. [CrossRef]

51. Nene, S.; Kaur, S.; Sumod, K.; Joshi, B.; Raghavarao, K.S.M.S. Membrane distillation for the concentration of raw cane-sugar syrup and membrane clarified sugarcane juice. Desalination 2002, 147, 157-160. [CrossRef]

52. Sakai, K.; Koyano, T.; Muroi, T.; Tamura, M. Effects of temperature and concentration polarization on water vapour permeability for blood in membrane distillation. Chem. Eng. J. 1988, 38, B33-B39. [CrossRef]

53. Sakai, K.; Muroi, T.; Ozawa, K.; Takesawa, S.; Tamura, M.; Nakane, T. Extraction of solute-free water from blood by membrane distillation. Am. Soc. Artif. Intern. Organ. Trans. 1986, 32, 397-400. [CrossRef]

54. Kujawski, W.; Krajewska, S.; Kujawski, M.; Gazagnes, L.; Larbot, A.; Persin, M. Pervaporation properties of fluoroalkylsilane (FAS) grafted ceramic membranes. Desalination 2007, 205, 75-86. [CrossRef]

55. Kujawa, J.; Cerneaux, S.; Kujawski, W. Removal of hazardous volatile organic compounds from water by vacuum pervaporation with hydrophobic ceramic membranes. J. Membr. Sci. 2015, 474, 11-19. [CrossRef]

56. Kujawa, J.; Cerneaux, S.; Kujawski, W. Highly hydrophobic ceramic membranes applied to the removal of volatile organic compounds in pervaporation. Chem. Eng. J. 2015, 260, 43-54. [CrossRef]

57. Amirilargani, M.; Sadrzadeh, M.; Sudholter, E.J.R.; de Smet, L.C.P.M. Surface modification methods of organic solvent nanofiltration membranes. Chem. Eng. J. 2016, 289, 562-582. [CrossRef]

58. Owens, D.K.; Wendt, R.C. Estimation of the surface free energy of polymers. J. Appl. Polym. Sci. 1969, 13, 1741-1747. [CrossRef]

59. Thomas, R.; Guillen-Burrieza, E.; Arafat, H.A. Pore structure control of PVDF membranes using a 2-stage coagulation bath phase inversion process for application in membrane distillation (MD). J. Membr. Sci. 2014, 452, 470-480. [CrossRef]

60. Walsh, R. Bond dissociation energy values in silicon-containing compounds and some of their implications. Acc. Chem. Res. 1981, 14, 246-252. [CrossRef]

61. Choi, W.; Tuteja, A.; Mabry, J.M.; Cohen, R.E.; McKinley, G.H. A modified Cassie-Baxter relationship to explain contact angle hysteresis and anisotropy on non-wetting textured surfaces. J. Colloid Interfaces Sci. 2009, 339, 208-216. [CrossRef] [PubMed]

62. Woldemariam, D.; Martin, A.; Santarelli, M. Exergy analysis of air-gap membrane distillation systems for water purification applications. Appl. Sci. 2017, 7, 301. [CrossRef]

63. Ko, C.-C.; Chen, C.-H.; Chen, Y.-R.; Wu, Y.-H.; Lu, S.-C.; Hu, F.-C.; Li, C.-L.; Tung, K.-L. Increasing the performance of vacuum membrane distillation using micro-structured hydrophobic aluminum hollow fiber membranes. Appl. Sci. 2017, 7, 357. [CrossRef]

64. Kujawa, J.; Kujawski, W. Driving force and activation energy in air-gap membrane distillation process. Chem. Pap. 2015, 69, 1438-1444. [CrossRef]

(C) 2017 by the authors. Licensee MDPI, Basel, Switzerland. This article is an open access article distributed under the terms and conditions of the Creative Commons Attribution (CC BY) license (http:/ / creativecommons.org/licenses/by/4.0/). 